International Journal of Linguistics, Literature and Culture
Available online at https://sloap.org/journals/index.php/ijllc/
Vol. 5, No. 4, July 2019, pages: $1 \sim 6$
ISSN: $2455-8028$
https://doi.org/10.21744/ijllc.v5n4.674

\title{
The Language Learning Assessment Using Technology For The Second Language Learners
}

\begin{abstract}
CrossMark
G. Menaka ${ }^{\text {a }}$

G. Sankar b
\end{abstract}

Article history:

Received: 27 March 2019

Accepted: 31 May 2019

Published: 11 June 2019

Keywords:

ELT;

foreign language;

language games;

second language learners;

teaching methods;

\begin{abstract}
Teacher education refers to the policies and procedures designed to equip prospective teachers with knowledge, attitudes, behaviors' and skills they require to perform their tasks effectively in the classroom, school, and wider community. The term 'teacher training' seems to be losing ground to 'teacher education'. In the era of globalization, when the world is changing so fast, the teaching field is also not unaffected. The approach of second language teaching that is ELT (English language teaching) has undergone a sea change. The "drill and practice" method is now considered to be rudimentary. Now, there are electronically sophisticated machines which have entered teaching-learning setting. Machine-assisted learning or e-learning is indeed an innovation in ELT. Even students find this new way of learning a second language to be amazing. Using language games is an efficient way of learning a second language.
\end{abstract}

2455-8028 ${ }^{\circ}$ Copyright 2019. The Author. This is an open-access article under the CC BY-SA license (https://creativecommons.org/licenses/by-sa/4.0/) All rights reserved.

\section{Author correspondence:}

G. Menaka,

Associate Professor, Department of English,

PSG College of Technology, Coimbatore-641 004, India.

Email address: sankarliterature@gmail.com

\section{Introduction}

This article brings out the characteristic feature of educational technology and its impact on teaching and learning (Astawa et al., 2017; Gahukar, 2014). It is natural for students to get tired after listening for a particular period of time. But machines would not get tired. This article throws light on the emerging need of smart classroom. The use of powerpoint and whiteboard are capturing the attention of the students in the classroom. The Audience response test allows for immediate feedback tests and classroom discussions (Heinze

a PSG College of Technology, Coimbatore, India

${ }^{\mathrm{b}}$ PSG College of Technology, Coimbatore, India 
\& Procter, 2010; Hopkins \& Cullen, 2007). The integration of technology was started in the early 1960s and 1970s. In the preliminary stage, people used tape recorders as a technological device to instruct the students, which later evolved as a communication laboratory. Every day people are getting access to some new technologies, which they use for English teaching. As the conventional teaching methods such as the chalk and talk method are outdated, these new technologies can be used as supplements to the classroom teaching to have a lively atmosphere in the classroom (Hounhanou, 2018; Indumathi, 2010). It is the need of the hour to integrate modern technologies to upgrade the level of English teaching. The modern technologies relax the mind of the students to get into the subject with full involvement. Indumathi observes: "New technologies in language learning by multiple intelligence and mixed abilities replace with old methods of teaching. In the multi-cultured community, the four basic skills are imparted in teaching with a variety and novelty. Hence they are enthusiastic in learning the language (Lata \& Kumar, 2010; Mahendra, 2016). Language can be learned by imitation, so one should hear more to develop his/her listening skills naturally they try to speak in the same styles as we learned our mother tongue" (35).

\section{Materials and Methods}

The usage of Internet has brought tremendous change in the field of teaching and enhancing English learning. It is believed that people tend to forget everything within three days after they hear. Repetitive exercises are given to the students so that they retain the language skills. Scenes from popular English films can be screened first without any running script on the screen (Menaka, 2018; Nitin, 2010). Then the students are asked to identify the words, script, etc., Again the scene will be repeated with the scripts on the screen. This kind of telecasting videotapes with and without script makes the students get familiar with the pronunciation, accent and word usage of English with interest. This method will make the students to repeat it again in their homes voluntarily.

Software's are available to develop LSRW skills. By incorporating suitable software through computers, the students will play it again and again with interest and try to improve their LSRW skills, which are most essential in this modernized world. Listening skills make one understand what another person speaks. Speaking skill is essential to convey the desire and idea of a person in the right way to the other. Reading skill is important to interpret what is given in the text. Writing is used to express our thoughts (Sankar, 2006; 2014, Sankar et al., 2016).

The usage of headphones in the lab makes the students have interest over the subject and induces them to repeat again and again instead of feeling bored. The communication lab provides freedom to the students so that the students need not depend on the teachers to enhance their skills. The students can have their own pace of learning and they can structure the learning process according to their needs. New software can be added and the students can view the technical developments instantly.

Videoconferencing is the method in which one person can access to the speeches of other persons in some other parts of the world. It is the live relay of a program, which is mostly used to view the lecture of a professor who resides in a foreign country. In short, it is very helpful for the students to understand what is going on in this world and to hear the speech of the topmost personalities in a lively manner. The most notable point in video conferencing is that the students can post questions immediately and get their answers at once (Sokolik, 2001; Suparsa et al., 2017).

Video Libraries are most essential in our fast and modernized world. This is helpful for those students who miss some interesting sessions. In this process, the teaching of the faculty will be recorded and made available to the students. The students can view the tapes in their leisure hours. The advantage in this method is that students can replay it when there is a necessity.

The Internet provides immense opportunities for learners of English. The words 'web' and 'log' are combined to form the portmanteau word "Blog". The blog allows the viewers to post their queries and comments. The blog is especially useful for first-time users as it is easier for them to become members. The learners can become members of a particular blogging community. In some blogs, the viewers can put videos and MP3. Spoken word entries can be made in blogs, which are audio friendly. This audio blogging may be linked to other blogs. Basically, a blog is an online journal because the student's thoughts, ideas, and opinions can be entered (Suryasa et al., 2017; Vijayalaksi-Imi, 2009). 


\section{Results and Discussions}

Blogging can be used for instructing the candidates when the teacher is off campus. The teacher can post his article or the instruction to the students, where the students are allowed to post their comments and queries. The teacher can answer the question through his blog. Blogging Mobile phones can also be utilized to enrich vocabulary skills by receiving new words daily. There are certain websites and services to provide new words every day. The only thing we have to do is that we should register our mobile number on particular websites. The educational role of Computers in learning a second language and the role of CALL.

Computer Assisted Language Learning) is significant. The teacher can use the latest technologies, which have the potential to transform the students from passive recipients of information into active participants. CALL is defined as the search for and study of applications of the Computer in language teaching and learning. Rakesh Damir observes:

The linguistic ability of the students can be enhanced by employing powerful innovative technological resources. The Computer Assisted Language Teaching (CALT), Computer Assisted Language Learning (CALL) are a few methods, which utilize modern technical facilities to the fullest use of teaching in teaching System (84).

TELL is the use of computer technology including hardware, software and the Internet to enhance teaching and learning of languages. It allows the students to get access with all the technologies available for the enhancement of English learning. Students are allowed to use online dictionaries, chat, and to view the various happenings around the world.

In the colleges, Educational Satellite labs must be established, whereby satellite programs of educational value like UGC's countrywide classrooms, Anna University programs, and other worldwide programs are recorded and students are given access to the recording either through big screen or small monitor. Internet is a commonly acknowledged term and widely used by people throughout the world. Students now use the Internet in the class to learn English. Online teaching inside the classroom seems to be interesting and makes the students find out the suitable materials for them. Students are instructed to do the grammar exercises which are available online. Through the Internet we can collect data from various sources for any instruction.

Podcasting is the integration of audio files where we can feed our own materials and ply it inside and outside of the classroom. Students use i-pods to hear their favorite music files. In the same way, they have their education in the form of entertainment. Vijayalakshmi observes: "Podcasting allows students to use their techbased entertainment systems for educational purposes. With it, we are able to move away from the traditional faceto-face training without losing the student-to-trainer relationship that is so effective in any learning process. Podcasts enable students and teachers to share information with anyone at any time. An absent student can download the podcast of the recorded lesson and is able to access the missed lectures. They could also access lectures of experts which may not otherwise be available because of geographical distance and other reasons." (97).

We cannot depend on books only. When we need a particular piece of information, we have to go through all the textbooks we have. In this present age, everything seems to be simple and available in our fingertips. The websites such as www.onestopenglish.com and www.nonstopenglish.com provide information regarding English. Pushp Lata and Sanjay Kumar observe: "It has become mandatory for the teachers of language and communication to adapt to the changing environment. In this direction, the appropriate use of OHP, LCD, Language laboratory and computer technology in communication courses, will help to enhance learner's autonomy, develop fluency in speaking and improve proficiency in writing among students." (12). Technology in teaching not only helps store information but also allows students to monitor their own learning and continually evaluate their own performance (33).

Some language games like word building, solving crossword puzzles, etc. have been popular for quite a long time. Now, certain new language games which are based on computer-aided technology have been developed and are available online as well as in the form of software. Use of technology does not mean that the role of a teacher is sidelined. Learners still need a mentor in the form of a teacher. It is just that the way of teaching a second language

Menaka, G., \& Sankar, G. (2019). The language learning assessment using technology for the second language learners. International Journal of Linguistics, Literature and Culture, 5(4), 1-6. https://doi.org/10.21744/ijllc.v5n4.674 
has changed. The traditional chalk-board method is gradually replaced by the innovative techno-friendly method in the teaching-learning atmosphere. Use of language games based on computer-aided technology is one of the most important emerging trends in ELT. So, teacher education should include workshops related to operating language games based on computer technology and organization of smart classes.

\section{Conclusion}

This paper thus, emphasizes the importance of language games and smart classes in ELT and how they can be integrated with classroom education so as to meet the challenges of the globalised era. Innovative Methods of ELT (English Language Teaching): Certain methods and approaches of ELT like Bilingual Method, Grammar-Translation Method, and Structural Oral Approach have been popular for quite a long time. However, the approach of second language teaching is changing now. The "drill and practice" method is now considered to be rudimentary. Now, some innovative methods like language games are also really useful in making students learn a second language better. Moreover, there are electronically sophisticated machines which have entered the teaching-learning setting. Machine -assisted learning or e-learning is indeed an innovation in ELT. These innovative learning environments are ahead of mainstream education and can serve as meaningful examples for renewal of learning environments in educational institutions. The concept of smart classes is also fast emerging as an effective way of ELT. Even students find these new methods of learning the second language to be amazing and Technology cannot take the place of the teacher completely in a classroom-learning situation. The modern tools are in addition to the inputs given by the teachers in the classrooms. The magic is real in that it helps the students to enhance their language learning in a fruitful way.

Conflict of interest statement and funding sources

The authors declared that they have no competing interest.

Statement of authorship

The authors have a responsibility for the conception and design of the study. The authors have approved the final article.

\section{Acknowledgments}

The authors would like to thank the editor team of IJLLC for their valuable time, support, and advice in completing the current article. 


\section{References}

Astawa, I. N., Handayani, N. D., Mantra, I. B. N., \& Wardana, I. K. (2017). Writing English language test items as a learning device: a principle of habit formation rules. International Journal of Social Sciences and Humanities, 1(3), 135-144. https://doi.org/10.29332/ijssh.v1n3.67

Gahukar, R. T. (2014). Potential and utilization of plant products in pest control. In Integrated Pest Management (pp. 125-139). Academic Press.

Heinze, A., \& Procter, C. (2010). The significance of the reflective practitioner in blended learning. International Journal of Mobile and Blended Learning (IJMBL), 2(2), 18-29.

Hopkins, D., \& Cullen, P. (2007). Cambridge Grammar for IELTS with Answers: Self-study Grammar; Reference and Practice. Ernst Klett Sprachen.

Hounhanou, A. V. (2018). Evaluating Benin EFL Learners Writing Composition during Final Exam. International Journal of Linguistics, Literature and Culture, 4(2), 9-23.

Indumathi, M. R. (2010). New Trends in Exploring the Unexplored in ELT-A Study. In Proceedings of the fifth National Conference, March (pp. 24-25).

Lata, P., \& Kumar, S. (2010). Technology Enabled Teaching of Professional Communication Courses: Problems and Perspectives. The Journal of English Language Teaching [India], 48, 3.

Mahendra, I. W. E. (2016). Contextual learning approach and performance assessment in mathematics learning. International Research Journal of Management, IT and Social Sciences, 3(3), 7-15.

Menaka, G. (2018). The assessment of developing speaking skills through technology in first year engineering college students. European Journal of Applied Linguistics Studies.

Nitin, B. (2010). Communicative English For Engineers And Professionals. Pearson Education India.

Sankar, G. (2006). A Comparative Study on Language Teaching Approaches and Cognitive Processes: A Paradigm Shift for Language Learners and Speakers. International Journal of English Literature and Culture, $2(7), 6$.

Sankar, G. (2014). Discriminatory policy among the undergraduate students towards racism and white privilege in America. Educational Research and Reviews, 9(19), 743-749.

Sankar, G. (2014). Discriminatory policy Among the Undergraduate Students to the Nature and scope to The Guide for College Teaching Approach. International Journal of Research, 1(6), 655-673.

Sankar, G. (2014). English language teaching is an assessment and natural approaches to the language learners with theory and practice. International Journal of English Literature and Culture, 2(9), 210-213.

Sankar, G., Soundararajan, R., \& Kumar, S. S. (2016). Language Learning and Language Acquisition: What Do the Learners Prefer?. Studies in Literature and Language, 13(2), 15-25.

Sokolik, M. (2001). Computers in language teaching. Teaching English as a second or foreign language, 477-488.

Suparsa, I. N., Mantra, I. B. N., \& Widiastuti, I. A. M. S. (2017). Developing learning methods of Indonesian as a foreign language. International Journal of Social Sciences and Humanities, 1(2), 51-57. https://doi.org/10.29332/ijssh.v1n2.41

Suryasa, I. W., Prayoga, I. G. P. A., \& Werdistira, I. W. A. (2017). An analysis of students motivation toward English learning as second language among students in Pritchard English academy (PEACE). International Journal of Social Sciences and Humanities, 1(2), 43-50. https://doi.org/10.29332/ijssh.v1n2.36

Vijayalaksi-Imi, S. (2009). Podcasting: An Effective Tool for Language Learning. Teaching english as a second language: a new pedagogy for a new century, 100.

Menaka, G., \& Sankar, G. (2019). The language learning assessment using technology for the second language learners. International Journal of Linguistics, Literature and Culture, 5(4), 1-6. https://doi.org/10.21744/ijllc.v5n4.674 


\section{Biography of Authors}

\begin{tabular}{|l|l|l||}
\hline & $\begin{array}{l}\text { Dr. G. Menaka, is working as Associate Professor, Department of English, PSG } \\
\text { College of Technology, Coimbatore-641 004, India. She has been published research } \\
\text { papers in various International and National Peer-reviewed Journals and She presented } \\
\text { many research papers at various International/national levels conferences, seminars, } \\
\text { and symposiums, she has given many guest lectures and invited talks at various } \\
\text { colleges in Tamil Nadu. } \\
\text { Email: menakareno@ @mail.com }\end{array}$ \\
\hline \hline
\end{tabular}

